\title{
Aqueous TISSUE EXTRACTS OF Conyza canadensis INHIBIT THE Germination and Shoot Growth of Three Native Herbs With No Autotoxic EFFects ${ }^{1}$
}

\author{
Extractos Aquosos de Conyza canadensis Inibem a Germinação e o Crescimento de Três \\ Espécies Daninhas sem Efeitos Autotóxicos
}

HU, G. ${ }^{2}$ and ZHANG, Z.H. ${ }^{2}$

\begin{abstract}
Conyza canadensis is a widespread weed species forming dense populations in most regions of China. Petri dish bioassays with aqueous extracts of the aboveground parts and roots of $C$. canadensis at three concentrations $\left(0.05,0.1\right.$, and $\left.0.2 \mathrm{~g} \mathrm{~mL}^{-1}\right)$ were undertaken to investigate the autotoxic effects of $C$. canadensis, and the possible effects on three dominant native weed species, Plantago asiatica, Digitaria sanguinalis and Youngia japonica. The results showed that seed germination and the shoot length of three native species were significantly inhibited by aqueous extracts of $C$. canadensis at almost all concentrations that generally increased with increasing extract concentration. However, the seed germination and shoot length of $C$. canadensis itself was not significantly affected by the same extracts at all concentrations. These results suggested that the potential allelopathic compounds produced by the tissue of $C$. canadensis may contribute to its invasive success in invading southern China.
\end{abstract}

Keywords: invasive alien weed, allelopathy, petri dish bioassay.

RESUMO - Conyza canadensis é uma espécie de planta daninha comum que forma populações densas na maioria das regiões da China. Foram realizados bioensaios em placas de Petri com extratos aquosos das partes visiveis e das raizes de $\boldsymbol{C}$. canadensis em três concentrações $(0,05$, 0,1 e 0,2 $\mathrm{g} \mathrm{mL}^{-1}$ ), a fim de investigar os efeitos autotóxicos dessa espécie, bem como os possíveis efeitos em três espécies nativas dominantes: Plantago asiatica, Digitaria sanguinalis $e$ Youngia japonica. Os resultados mostraram que a germinação de sementes e o crescimento de rebentos das três espécies nativas eram inibidos significativamente pelos extratos aquosos de C. canadensis em quase todas as concentrações, que aumentaram geralmente com uma concentração cada vez maior de extratos. Contudo, a germinação de sementes e o crescimento de rebentos da própria C. canadensis não foram alterados significativamente pelos mesmos extratos em todas as concentrações. Esses resultados sugerem que os potenciais compostos alelopáticos produzidos pelo tecido de C. canadensis podem contribuir para o seu sucesso invasivo no sul da China.

Palavras-chave: planta daninha invasiva alienígena, alelopatia, bioensaio em placa de Petri.

\section{INTRODUCTION}

Conyza canadensis (Asteraceae) is an annual invasive alien and unwanted weed native to North America (Weaver, 2001). It is a versatile and highly adaptive invader that is found in many parts of the world (Dauer et al., 2007; Zaplata, 2011). It was first recorded in Yantai, Shandong province of China in 1862 (Xie et al., 2001), and is now

\footnotetext{
Recebido para publicação em 24.9.2012 e aprovado em 26.11.2012.

2 Guangxi Teachers Education University, Nanning, China, <gxtczzh@gmail.com>.
} 
widely distributed throughout the 28 provinces and listed as one of the most noxious, invasive plants in China (Weber et al., 2008). This plant generally grows $0.5-1 \mathrm{~m}$ tall, and often forms dense populations in most habitats, such as fallow fields, orchard, pastures, roadsides, etc. (Main et al., 2006). It is considered an important agricultural weed because it can reduce agricultural yields by $90 \%$ at high densities (100-200 plants $\mathrm{m}^{-2}$ ) (Shields et al., 2006). Seed production is robust with an estimated 100,000 wind-dispersed seeds produced per plant when densities reached 200 plants $\mathrm{m}^{-2}$ and 200,000 seeds when plant densities were low (10 plants $\mathrm{m}^{-2}$ ) (Bhowmik \& Bekech, 1993). On invasion, it establishes quickly in the alien environment, resulting in changes in the structure and function of the native ecosystem.

Allelopathy is a process whereby plants provide themselves with a competitive advantage by putting phytotoxins into the near environment. It is known to play an important role in affecting the community structure, including plant dominance and succession (Lambers et al., 1998). Recently, numerous studies have demonstrated the allelopathic effects of invasive plants on native species in the invaded ranges and provided compelling evidence for allelopathy as an important component of the competitive success of some invaders (Bais et al., 2003; Hierro \& Gallaway, 2003; Prati \& Bossdorf, 2004; Dorning \& Cipollini, 2006; Cipollini et al., 2008; Inderjit et al., 2008; Thorpe et al., 2009; Chapla \& Campos, 2010; Pisula \& Meiners, 2010). Although the noxious $C$. canadensis poses a very serious threat to the diversity or abundance of native plant species and agricultural productivity in China, the mechanisms of the invasion of $C$. canadensis are still poorly understood. A recent study has reported that a total of 42 compounds, including phenol, ketone, acid, alcohol, aldehyde, ester, terpene, etc., were identified from an extract of C. canadensis (Zhang, 2010). Among these, phenol, ketone, and acid were the main components, which might show the allelopathic effects (Zhang, 2010). Shaukat et al. (2003) reported that the aqueous extract of $C$. canadensis at different concentrations $(25$, 50,75 , and $100 \%$ stock solution) inhibited the germination, root, and shoot growth of six crop species. Presumably, the dominance of C. canadensis in its invaded habitats might be related to chemical interference or allelopathy, which gives it an additional advantage over neighboring native plants.

Because of difficulties in separating the allelopathic effects from resource competition, it is extremely difficult to demonstrate allelopathy in the field (Bais et al., 2003). Instead, extensive research has successfully shown the potential for allelopathy in invasive plants using tissue extracts (Dorning \& Cipollini, 2006; Yang et al., 2007; Hussain et al., 2011). A similar approach was applied to study the effects of $C$. canadensis on seed germination and the shoot growth of three native species and C. canadensis itself under laboratory conditions by using aqueous extracts at different concentrations from the aboveground parts and roots of $C$. canadensis. We hypothesized that the presence of the extracts of $C$. canadensis would reduce seed germination and the shoot length of these native species. In contrast, the seeds and seedlings of $C$. canadensis can explore their adaptive benefit for its own extracts and, therefore, they should be resistant to inhibitory allelopathic effects.

\section{MATERIALS AND METHODS}

\section{Sample collection}

Three native herb species, Plantago asiatica (Plantaginaceae), Digitaria sanguinalis (Poaceae), Youngia japonica (Asteraceae), and C. canadensis itself were chosen as target species. These native species were often the dominant weed species in most field sites such as roadsides, agricultural fields, disturbed grasslands, and abandoned fields prior to C. canadensis invasion in southern China. From June to October 2010, the seeds of the four target species were collected from the abandoned fields and roadsides in the suburbs of Nanning city, southern China. All the collected seeds were visually examined and all damaged seeds were discarded. After air drying, these seeds were stored in plastic bottles in the dark at $4{ }^{\circ} \mathrm{C}$ until further use.

Field grown C. canadensis whole plants were collected in situ in Mar 2011. The fresh 
plants were immediately taken to the laboratory, and separated into aboveground (leaf and stem) and belowground (root) components. Each component was first cleaned to remove the dirt, air dried, and ground into powder using a mechanical grinder. The powder was instantly passed through a 100-mesh sieve and kept for use.

\section{Extraction procedure}

Twenty grams of each ground component were extracted by soaking in $100 \mathrm{~mL}$ of distilled water at $25{ }^{\circ} \mathrm{C}$ for $36 \mathrm{~h}$ in a shaker. The aqueous extracts were then filtered twice through Whatman No. 1 filter paper (particle retention of $11 \mu \mathrm{m}$ ), and $0.2 \mathrm{~g} \mathrm{~mL}^{-1}$ aqueous extract was obtained. Using this extract as stock solution, $0.1 \mathrm{~g} \mathrm{~mL}^{-1}$ and $0.05 \mathrm{~g} \mathrm{~mL}^{-1}$ extracts were prepared by dilution. The three concentrations $\left(0.05,0.1\right.$, and $\left.0.2 \mathrm{~g} \mathrm{~mL}^{-1}\right)$ of the aqueous extracts of aboveground parts and the roots of $C$. canadensis were tested for allelopathic potential by a seed germination bioassay.

\section{Petri dish bioassay}

In March 2011, the seeds of the four species were sterilized in $\mathrm{NaOCl}(5 \% \mathrm{v} / \mathrm{v})$ and washed thrice with distilled water before sowing. Twenty seeds of each species were placed on two layers of filter paper in glass Petri dishes $(9 \mathrm{~cm}$ diameter). Five $\mathrm{mL}$ of each extract solution were added to the Petri dishes, while the control treatment $(\mathrm{CK})$ received $5 \mathrm{~mL}$ of distilled water. The Petri dishes and filter paper were used as a sterile medium. Three replicates of each treatment were incubated in an illuminated cultivation cabinet setting at $25^{\circ} \mathrm{C} / 20^{\circ} \mathrm{C}$ day/night temperature with $70 \%$ relative humidity and a $12 / 12 \mathrm{~h}$ light/dark regime. An additional $1 \mathrm{~mL}$ of each solution was added every $48 \mathrm{~h}$ thereafter. The germination was assessed after every $24 \mathrm{~h}$ by counting the number of germinated seeds for up to one week. Seeds were considered germinated when radicles could be observed by the naked eye. After one week, all Petri dishes were transferred to a cold chamber at $4{ }^{\circ} \mathrm{C}$ in order to stop seedling growth and then the shoot length was recorded with a measuring tape.

\section{Statistical analysis}

Germination bioassays were analyzed in a randomized design with three replications. The collected data were statistically analyzed by using a one-way ANOVA, and the LSD test was used to determine the differences between the treatment means at the $5 \%$ probability level. Statistical analysis was conducted using SPSS 11.5 software (SPSS Inc., Chicago, Illinois, USA).

\section{RESULTS}

The seed germination of $C$. canadensis, $P$. asiatica, D. sanguinalis, and $Y$. japonica reached an average of $70.9 \%, 90.2 \%, 84.3 \%$, and $60.2 \%$, respectively, in the control treatment by the end of the experiment (Figure 1A and B). Both the aqueous extracts of aboveground parts and the roots of C. canadensis had no significant effect on its own germination at all three concentrations $(0.05,0.1$, and $0.2 \mathrm{~g} \mathrm{~mL})$ compared with the control. In contrary to C. canadensis, extracts at almost all concentrations significantly decreased the germination percentage of other species and the percent inhibition increased with increasing concentration of extracts, so that the lowest germination percentage was observed at $0.2 \mathrm{~g}$ mL extracts. Furthermore, the aqueous extract of aboveground parts of C. canadensis showed stronger inhibition than root extract. For example, the final germination of $P$. asiatica, D. sanguinalis, and $Y$. japonica seeds receiving $0.2 \mathrm{~g} \mathrm{~mL}^{-1}$ of aqueous extract of aboveground parts, was only $20.2 \%, 14.5 \%$, and $6.2 \%$, respectively (Figure $1 \mathrm{~A}$ ), while $31.5 \%$, $32.2 \%$, and $22.1 \%$, respectively, at the same concentrations of root extracts (Figure 1B).

The final shoot length of $C$. canadensis was not significantly affected by its own extract at all concentrations (Figure 2A and B). However, the shoot length of three native species was significant inhibited by both aqueous extracts of aboveground parts and roots of $C$. canadensis at most concentrations. The shoot length generally reduced with an increasing concentration of extracts for each of the native species. The extract of aboveground parts showed stronger inhibitory effects than root extract on shoot growth. Extract of aboveground parts at a lowest concentration $(0.05 \mathrm{~g} \mathrm{~mL})$ 

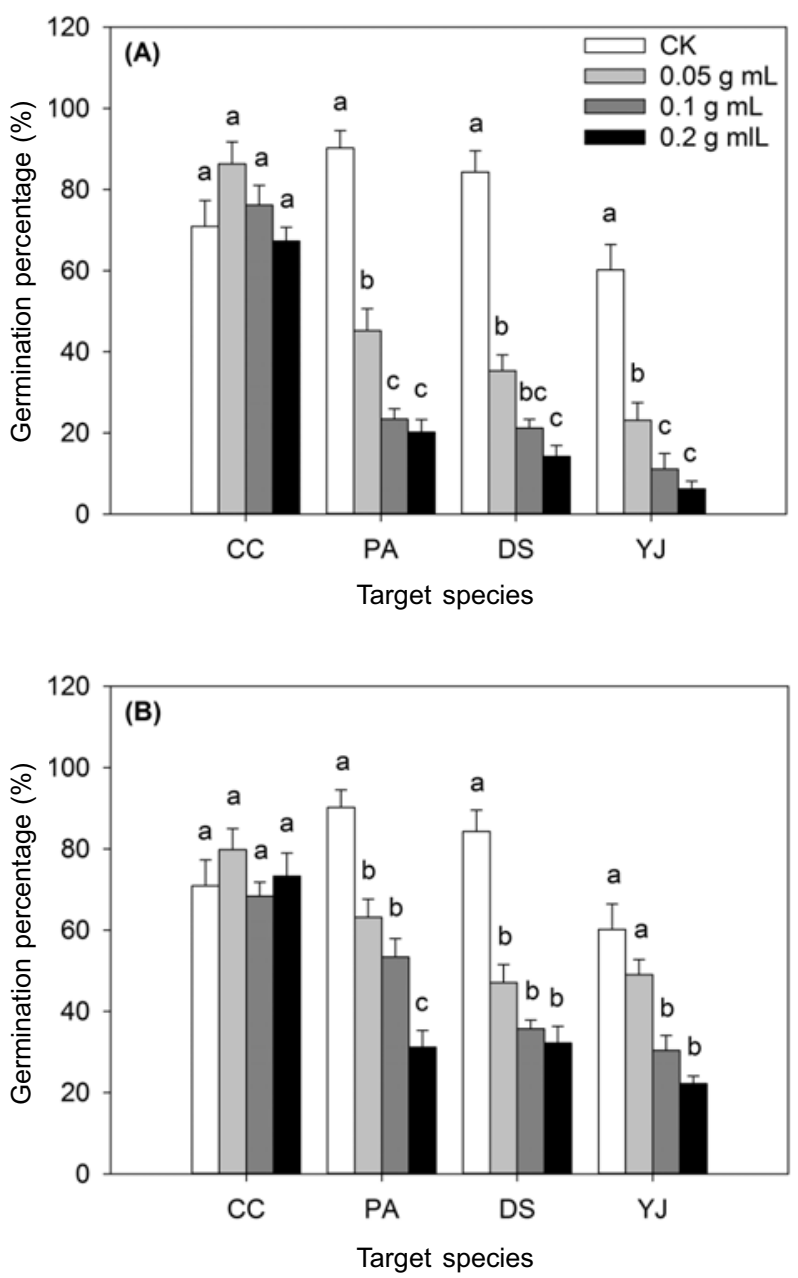

Figure 1 - Effects of different aqueous extract concentrations of aboveground parts (A) and roots (B) of C. canadensis on the seed germination of four target species. Each column represents the mean value \pm standard error from three replicates. CC, Conyza canadensis; PA, Plantago asiatica; DS, Digitaria sanguinalis; YJ, Youngia japônica.

significantly reduced the shoot length of $P$. asiatica and Y. japonica (Figure 2A), while there was no significant reduction from root extracts at the lowest concentration (Figure 2B).

\section{DISCUSSION}

Shoot extracts of $C$. canadensis and volatile compounds from the inflorescence of invasive Conyza albida, a closely related species, exerted significant inhibitory effects on the germination and growth of several crop species (Economou et al., 2002; Shaukat et al., 2003). In the present experiment, the aqueous
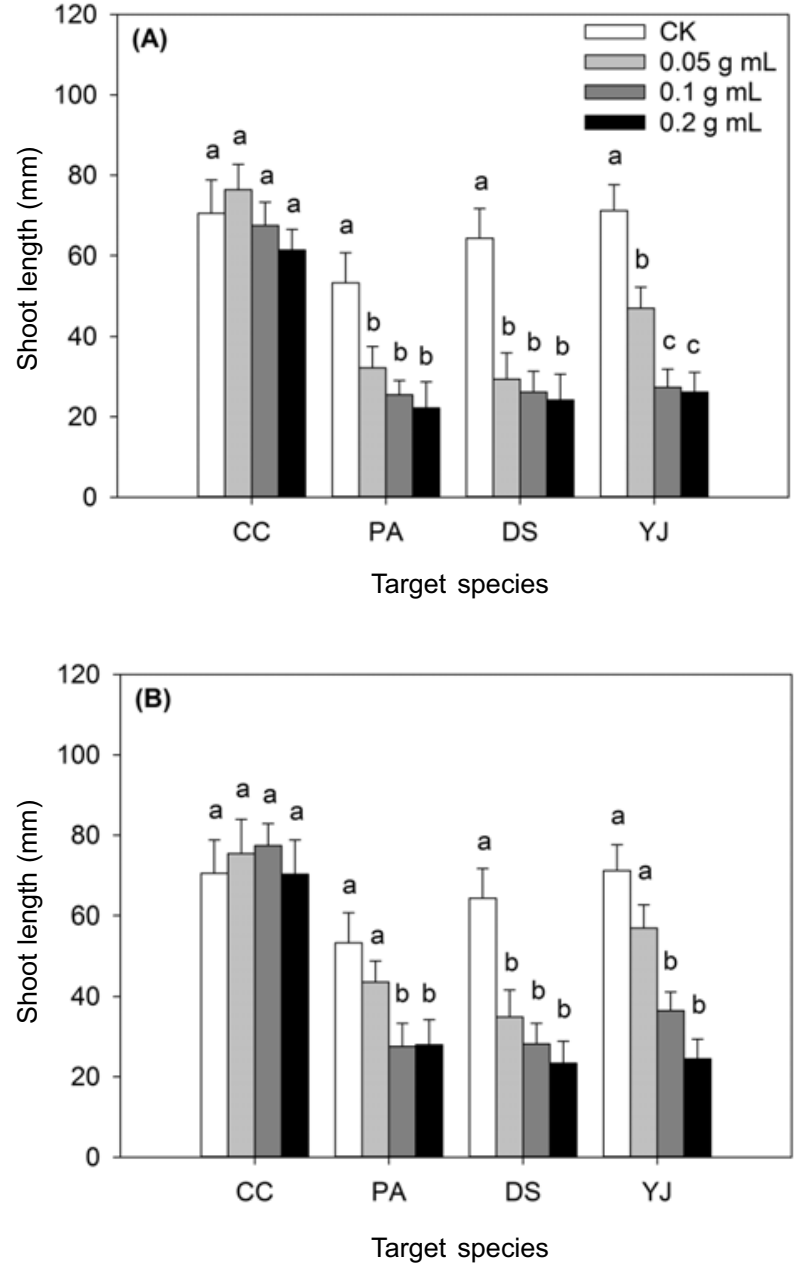

Figure 2 - Effects of different aqueous extract concentrations of aboveground parts (A) and roots (B) of C. canadensis on the shoot length of four target species. Each column represents the mean value \pm standard error from three replicates. CC, Conyza canadensis; PA, Plantago asiatica; DS, Digitaria sanguinalis; YJ, Youngia japonica.

extracts of aboveground parts and the roots of C. canadensis greatly inhibited seed germination and the shoot growth of three dominant native herb species, $P$. asiatica, $D$. sanguinalis, and Y. japonica, under laboratory conditions, even at a low concentration $(0.05 \mathrm{~g} \mathrm{~mL})$. Allelopathic compounds that have phytotoxic or at least fitness-reducing effects may be novel for plant competitors without a co-evolutionary history (Callaway \& Aschehoug, 2000; Hierro \& Callaway, 2003; Callaway \& Ridenour, 2004). These non-coevolved competitors may be susceptible to novel phytochemicals in the 
native range (Callaway \& Aschehoug, 2000; Inderjit et al., 2008). The inhibitory effects on target native species were possibly due to the presence of allelochemicals in C. canadensis plant. In this study, germination percentage and shoot length generally reduced with the increasing concentration of extracts for each of the native species, indicating that the extracts suppress the target species in a concentration dependent manner. This finding is consistent with those reported elsewhere for other invasive alien plant species (Sun et al., 2006; Yang et al., 2007).

Some invasive plants release numerous allelochemicals as leachates as they decompose and through volatilization as living tissues into their surrounding environment, causing native plants to decline (Bais et al., 2003; Inderjit et al., 2008; Thorpe et al., 2009). Our results suggested that the natural extracts of $C$. canadensis have the potential to inhibit the germination and growth of competing plants in the field. The potential allelopathic effects could contribute to the invasion success of $C$. canadensis in its introduced ranges, and its success cannot just be attributed to a single trait, such as the huge production of wind-dispersed seeds (Bhowmik \& Bekech, 1993; Shields et al., 2006; Main et al., 2006).

Interestingly, the aqueous extracts of C. canadensis at all concentrations had no significant effect on its own the germination and shoot length. Lawrence et al. (1991) showed that the extracts of Ailanthus altissima inhibited the growth of germinated seedlings of 8 North American native species with no autotoxic effects. Dorning \& Cipollini (2006) also found an invasive shrub, Lonicera maackii that inhibited seed germination in both native and non-native forbs, without any autotoxicity. For an allelopathic compound to have adaptive value for a plant, the plant should be resistant to autotoxic effects (Cope, 1982; Olson \& Wallander, 2002; Inderjit \& Duke, 2003). Many different mechanisms exist for the prevention of autotoxicity by allelochemicals in plants, including the conjugation of active compounds with sugars (Inderjit \& Duke, 2003). Resistance to the toxic effects of allelopathic compounds released by a single individual and its conspecific neighbors may explain the cause of the rapid formation of very dense populations of $C$. canadensis in the field.

Allelopathic compounds are found in different parts of a plant body (roots, stems, ûowers, and leaves) and different parts of the same plant may vary in their allelopathic effects (Dorning \& Cipollini, 2006; Barbosa et al., 2008; Hsu \& Kao, 2009; Hussain et al., 2011). Leaf and (or) stem extract(s) had a greater effect than root extract on seed germination (Dorning \& Cipollini, 2006; Suwal et al., 2010). In this study, the extract of aboveground parts of $C$. canadensis appeared to have a more negative effect on the germination percentage and shoot length of three native species than root extracts, although the results were not statistically compared. This suggested a greater concentration of diffusible active compound in the leaves and stems than in the roots, or a variation in the chemical composition between the tissues.

Although the present results are laboratory based, it was still indicated that $C$. canadensis has the capability to release allelopathic components through water. We can assume that the allelopathic components are watersoluble and diffusible from intact plant tissue. These allelopathic components may generally accumulate in the field soil to a physiologically active level and also probably be lost gradually from the soil through degradation or binding with other chemical compounds (Inderjit \& Weston, 2000; Pisula \& Meiners, 2010). Inderjit \& Duke (2003) stated that plants release phytochemicals from plant tissues, and their incorporation to the soil could be accelerated by leaching thus facilitating their harmful effects in the field. Therefore, inhibitory effects of compounds produced by tissues of $C$. canadensis may persist for some time after the removal of $C$. canadensis in its invaded habitats. Identifying and studying the persistence of allelopathic compounds in the field soil would help guide restoration efforts.

In conclusion, our experiment using a Petri dish bioassay showed that C. canadensis can successfully inhibit the performance of some native plants with no autotoxic effects. This result suggests that there was a strong potential phytotoxic effect of invasive C. canadensis on some native species and this 
effect might contribute to its invasive success in southern China. Although our experiment was a preliminary laboratory study it still provides encouraging results and a basis for future research.

\section{ACKNOWLEDGEMENTS}

This study was supported by the Scientific Research Foundation of the Education Department of Guangxi Zhuang Autonomous Region (grant No. 201106LX296) and the Key Laboratory of Beibu Gulf Environment Change and Resources Utilization (Guangxi Teachers Education University), Ministry of Education, China (grant No. BBG1103).

\section{LITERATURE CITED}

BAIS, H. P. et al. Allelopathy and alien plant invasion: from molecules and genes to species interactions. Science, v. 301, n. 5638, p. 1377-138, 2003.

BARBOSA, E. G. et al. Allelopathic evidence in Brachiaria decumbens and its potential to invade the Brazilian cerrados. Braz. Arch. Biol. Technol., v. 51, n. 4, p. 825-831, 2008.

BHOWMIK, P. C.; BEKECH, M. M. Horseweed (Conyza canadensis) seed production, emergence, and distribution in no-tillage and conventional-tillage corn (Zea mays). Agron.

Trends Agric. Sci., v. 1, n. 1, p. 67-71, 1993.

CALLAWAY, R. M.; ASCHEHOUG, E. T. Invasive plant versus their new and old neighbors: A mechanism for exotic invasion. Science, v. 290, n. 5491, p. 521-523, 2000.

CALLAWAY, R. M.; RIDENOUR, W. M. Novel weapons: Invasive success and the evolution of increased competitive ability. Front. Ecol. Environ., v. 2, n. 8, p. 436-443, 2004.

CHAPLA, T. E.; CAMPOS, J. B. Allelopathic evidence in exotic guava (Psidium guajava L.). Braz. Arch. Biol. Technol., v. 53, n. 6, p. 1359-1362, 2010.

CIPOLLINI, D. et al. Contrasting effects of allelochemicals from two invasive plants on the performance of a nonmycorrhizal plant. Intern. J. Plant Sci., v. 169, n. 3, p. 371-375, 2008.

COPE, W. A. Inhibition of germination and seedling growth of 8 forage species by leachates from seeds. Crop Sci., v. 22, n. 6, p. 1109-1111, 1982.

DAUER, J. T. et al. Temporal and spatial dynamics of longdistance Conyza canadensis seed dispersal. J. Appl. Ecol., v. 44, n. 1, p. 105-114, 2007.

Planta Daninha, Viçosa-MG, v. 31, n. 4, p. 805-811, 2013
DORNING, M.; CIPOLLINI, D. Leaf and root extracts of the invasive shrub, Lonicera maackii, inhibit seed germination of three herbs with no autotoxic effects. Plant Ecol., v. 184, n. 2, p. 287-296, 2006.

ECONOMOU, G. et al. Allelopathic effect of Conyza albida on Avena sativa and Spirodela polyrhiza. J. Agron. Crop Sci., v. 188, n. 4, p. 248-53, 2002.

HIERRO, J. L.; CALLAWAY, R. M. Allelopathy and exotic plant invasion. Plant Soil, v. 256, n. 1, p. 29-39, 2003.

HSU, H. M.; KAO, W. Y. Contrasting effects of aqueous tissue extracts from an invasive plant, Bidens pilosa L. var. radiata, on the performance of its sympatric plant species. Taiwania, v. 54, n. 3, p. 255-260, 2009.

HUSSAIN, M. I. et al. Allelopathic potential of Acacia melanoxylon on the germination and root growth of native species. Weed Biol. Manag., v. 11, n. 1, p. 18-28, 2011.

INDERJIT, I. et al. Allelopathy and plant invasions: traditional, congeneric, and biogeographical approaches. Biol. Invasions, v. 10, n. 6, p. 875-890, 2008.

INDERJIT, I.; DUKE, S. O. Ecophysiological aspects of allelopathy. Planta, v. 217, n. 4, p. 529-539, 2003.

INDERJIT, I.; WESTON, L. A. Are laboratory bioassays for allelopathy suitable for prediction of field responses? J.

Chem. Ecol., v. 26, n. 9, p. 2111-2118, 2000.

LAMBERS, H. et al. Plant physiological ecology. Berlin: Springer-Verlag, 1998.

LAWRENCE, J. G. et al. The ecological impact of allelopathy in Ailanthus altissima (Simaroubaceae). Am. J. Bot., v. 78, n. 7, p. 948-958, 1991.

MAIN, C. L. et al. Biotic and abiotic factors influence horseweed emergence. Weed Sci., v. 54, n. 6, p. 1101-1105, 2006.

OLSON, B. E.; WALLANDER, R. T. Effects of invasive forb litter on seed germination, seedling growth and survival. Basic Appl. Ecol., v. 3, n. 4, p. 309-317, 2002.

PISULA, N. L.; MEINERS, S. J. Relative allelopathic potential of invasive plant species in a young disturbed woodland. J. Torrey Bot. Soc., v. 137, n. 1, p. 81-87, 2010.

PRATI, D.; BOSSDORF, O. Allelopathic inhibition of germination by Alliaria petiolata (Brassicaceae). Am. J. Bot., v. 91, n. 2, p. 285-288, 2004.

SHAUKAT, S. S. et al. Allelopathic responses of Conyza canadensis (L.) Cronquist: a cosmopolitan weed. Asian J. Plant Sci., v. 2, n. 14, p. 1034-1039, 2003. 
SHIELDS, E. J. et al. Horseweed (Conyza canadensis) seed collected in the planetary boundary layer. Weed Sci., v. 54, n. 6, p. 1063-1067, 2006.

SUN, B. Y. et al. Allelopathic effects of extracts from Solidago canadensis L. against seed germination and seedling growth of some plants. J. Environ. Sci. China., v. 18, n. 2, p. 304-306, 2006.

SUWAL, M. M. et al. Allelopathic effects of Chromolaena odorata (L.) King \& Robinson on seed germination and seedlings growth of Paddy and Barnyard Grass. Sci. World, v. 8, n. 8, p. 73-75, 2010.

THORPE, A. S. et al. Root exudate is allelopathic in invaded community but not in native community: field evidence for the novel weapons hypothesis. J. Ecol., v. 97, n. 4, p. 641-645, 2009.

WEAVER, S. E. The biology of Canadian weeds.115. Conyza canadensis. Can. J. Plant Sci., v. 81, n. 4, p. 867-875, 2001.
WEBER, E. et al. Invasive alien plants in China: diversity and ecological insights. Biol. Invasions, v. 10, n. 8, p. 1411-1429, 2008.

XIE, Y. et al. Invasive species in China: an overview. Biodivers. Conserv., v. 10, n. 8, p. 1317-1341, 2001.

YANG, R. Y. et al. Allelopathic effects of invasive Solidago canadensis L. on germination, root growth of native Chinese plants. Allelopathy J., v. 19, n. 1, p. 241-248, 2007.

ZAPLATA, M. K. et al. Immediate shift towards source dynamics: the pioneer species Conyza canadensis in an initial ecosystem. Flora, v. 206, n. 11, p. 928-934, 2011.

ZHANG, S. Study on invasive biology of alien plant Conyza canadensis. 2010. 264 f. Dissertation (Master of Science) College of Life and Environmental Sciences, Shanghai Normal University, Shanghai, 2010. 